\title{
Cardiac implantable electronic device malfunction due to twiddler's syndrome in a patient with bipolar affective disorder
}

\author{
Jonathan Senior, Michael Kuehl
}

Cardiology, University Hospital Coventry, Coventry, UK

\section{Correspondence to}

Dr Jonathan Senior: jonathan.senior@nhs.net

Accepted 2 October 2021
Check for updates

(c) BMJ Publishing Group Limited 2021. No commercial re-use. See rights and permissions. Published by BMJ.

\begin{tabular}{|l|}
\hline To cite: Senior J, \\
Kuehl M. BMJ Case \\
Rep 2021;14:e245978. \\
doi:10.1136/bcr-2021- \\
245978 \\
\hline
\end{tabular}

\section{DESCRIPTION}

A 49-year-old man presented to our emergency department with dyspnoea and fluid overload. He denied any chest pain. Comorbidities included non-dilated ischaemic cardiomyopathy and bipolar affective disorder. An admission ECG demonstrated sinus rhythm with left bundle branch block (QRS duration $=126 \mathrm{~ms}$ ). A chest X-ray confirmed pulmonary congestion. Blood tests were unremarkable, with no evidence of infection. Highly sensitive troponin $\mathrm{T}$ was mildly elevated at $34 \mathrm{ng} / \mathrm{L}$. He was successfully treated for decompensated heart failure with furosemide and dobutamine, achieving an $11 \mathrm{~kg}$ diuresis. Transthoracic echocardiography confirmed severe biventricular dilatation with global left ventricular (LV) systolic impairment and an LV ejection fraction of $16 \%$.

He was referred for assessment at our regional transplant centre and listed for a biventricular pacemaker following discussion at our multidisciplinary team (MDT) meeting. Two weeks later, he returned for an uneventful elective implant of a cardiac resynchronisation therapy with defibrillator (CRT-D) device.

Nine days on, he again presented to our emergency department with dyspnoea, testing positive for COVID-19 pneumonitis. On day 4 of this admission, he required transfer to the intensive care department for inotropic support. Unfortunately, this experience caused a significant deterioration in his mental health with paranoid thoughts and concerning behaviours. Following a thorough psychiatric assessment, he was discharged to a psychiatric hospital on day 10 .

Six weeks later, he was repatriated to our centre with swelling at the site of CRT-D implant, with concerns raised regarding a possible wound infection. However, C reactive protein was just $4 \mathrm{mg} / \mathrm{L}$ with a white cell count of $6.2 \times 10^{9} / \mathrm{L}$. A chest X-ray demonstrated retraction of the leads back to the generator pocket, with the defibrillator coil clearly visible in the left subclavian vein (figure 1). He held a delusional belief that this was caused following an assault by hospital security staff, although there was no evidence to support this claim. He vehemently denied manipulating the device.

The patient was taken to the cardiac catheterisation laboratory whereupon the reopening of the pocket, all three leads of the CRT-D appeared heavily entangled with no evidence of infection (figure 2). The device was extracted without complication and the MDT consensus was to avoid reimplantation.

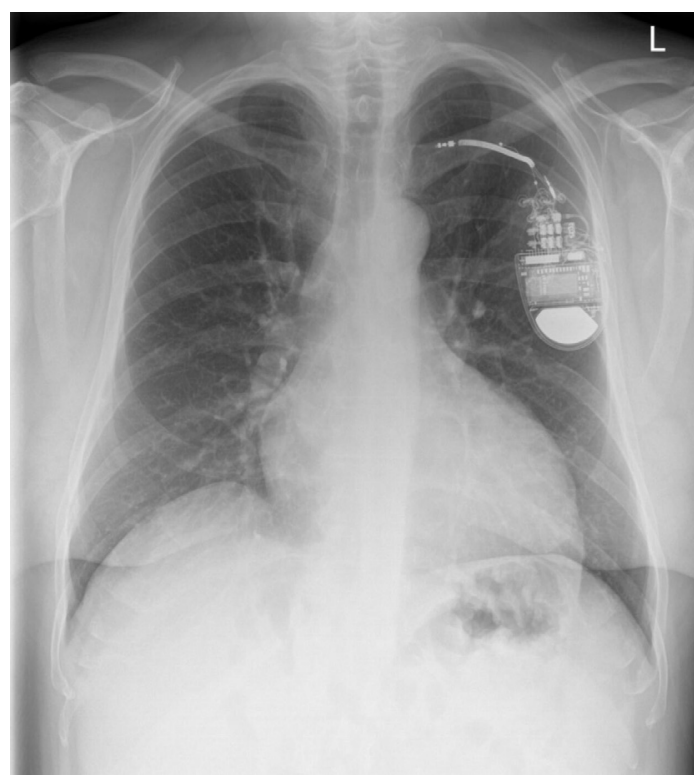

Figure 1 Chest X-ray showing entanglement of all three CRT-D leads in the pulse generator pocket with retraction of the defibrillator coil visible in the left subclavian vein. CRT-D, cardiac resynchronisation therapy with defibrillator.

Twiddler's syndrome was first described $1968,{ }^{1}$ it is a rare but serious cause of cardiac implantable electronic device malfunction typically occurring within a year of implant widely reported in elderly patients with cognitive impairment ${ }^{2}$ but only recently observed in a patient with schizophrenia. ${ }^{3}$

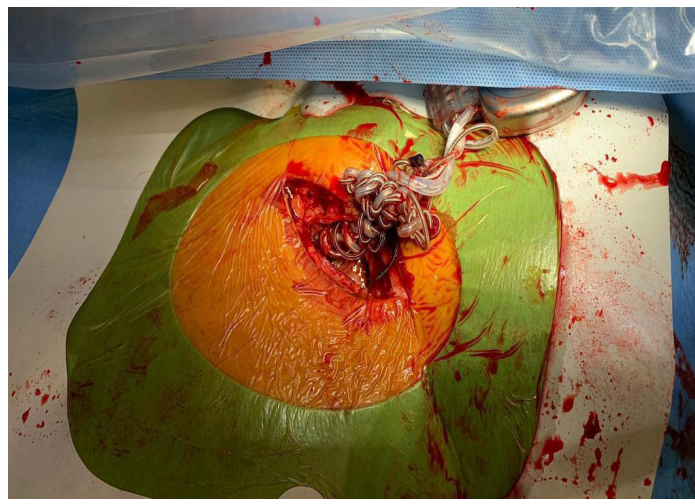

Figure 2 The three leads of the CRT-D device were heavily entangled on the reopening of the pulse generator pocket. CRT-D, cardiac resynchronisation therapy with defibrillator. 
It may present with pacemaker loss of capture, diaphragmatic irritation or inappropriate therapies from a defibrillator. The implantable cardioverter defibrillator plays a vital role in the prevention of sudden death, however, implantation can have a detrimental impact on psychological well-being, particularly in younger individuals. ${ }^{4}$

Patients with mental health disorders should not be denied device therapy, however, this case highlights the importance of a thorough psychosocial assessment prior to implantation in patients with significant psychiatric comorbidity. Patients and caregivers should be carefully counselled beforehand and other

\section{Learning points}

- Twiddler's syndrome is a very rare but potentially serious complication of cardiac implantable device therapy.

- Implantable cardioverter defibrillators play a vital role in the prevention in sudden death, but may have a detrimental impact on psychological well-being.

- Patients with underlying mental health conditions should not be denied device therapy, but may benefit from a thorough psychosocial assessment prior to device implantation. technical approaches such as subpectoral implantation may be considered.

Contributors Both authors were heavily involved in the production of the manuscript and then finalising approval of the version published. All authors are agreeable to be accountable for the article and to ensure that all questions regarding the accuracy or integrity of the article are investigated and resolved. JS: planning, conception, sought patient consent and wrote article. MK: performed device extraction, arranged appropriate clinical photography, reviewed and edited manuscript prior to submission.

Funding The authors have not declared a specific grant for this research from any funding agency in the public, commercial or not-for-profit sectors.

Competing interests None declared.

Patient consent for publication Consent obtained directly from patient(s).

Provenance and peer review Not commissioned; externally peer reviewed.

\section{REFERENCES}

1 Bayliss CE, Beanlands DS, Baird RJ. The pacemaker-twiddler's syndrome: a new complication of implantable transvenous pacemakers. Can Med Assoc $J$ 1968;99:371-3.

2 Salahuddin M, Cader FA, Nasrin S, et al. The pacemaker-twiddler's syndrome: an infrequent cause of pacemaker failure. BMC Res Notes 2016;9:32.

3 Olesen LL. Schizophrenia as a risk factor for pacemaker failure due to twiddler's syndrome. The Cardiologist 2020:2691-5685.

4 Ingles J, Sarina T, Kasparian N, et al. Psychological wellbeing and posttraumatic stress associated with implantable cardioverter defibrillator therapy in young adults with genetic heart disease. Int J Cardio/ 2013;168:3779-84.

Copyright 2021 BMJ Publishing Group. All rights reserved. For permission to reuse any of this content visit

https://www.bmj.com/company/products-services/rights-and-licensing/permissions/

BMJ Case Report Fellows may re-use this article for personal use and teaching without any further permission.

Become a Fellow of BMJ Case Reports today and you can:

- Submit as many cases as you like

- Enjoy fast sympathetic peer review and rapid publication of accepted articles

- Access all the published articles

- Re-use any of the published material for personal use and teaching without further permission

Customer Service

If you have any further queries about your subscription, please contact our customer services team on +44 (0) 2071111105 or via email at support@bmj.com.

Visit casereports.bmj.com for more articles like this and to become a Fellow 